\title{
ANALISIS PRODUK KOSMETIK IMPOR TERKAIT BRAND DAN PENGARUHNYA TERHADAP PEMBELIANKOSMETIK IMPOR DI SAMARINDA, KALIMANTAN TIMUR
}

\author{
Syarifah Aifa Fahira \\ Drs.ec.H.Ahmad Zafrullah Tn.,M.S \\ Idfi Setyaningrum, S.Si.,M.Si \\ Fakultas Bisnis dan Ekonomika, Universitas Surabaya
}

\begin{abstract}
This study discusses about imported cosmetic products which are beauty products that are becoming a great choice for Indonesian women, where most of the imported products have higher quality brand than local products. This study uses a quantitativedescriptive approach that is empirical inductive namely data collection, data analysis, based on facts and previous research in the field. This research uses a quantitative approach through a survey method and is carried out with an explanatory approach using a Likert scale. Respondents were asked to convey their level of agreement about the values and influences between the variables to be measured. The analytical method used in this study is the the method of multiple linear analysis with statistical methods using the Statistical Solution and Services (SPSS) version 24 software tools. The results of the analysis that have been done show that Brand Image has a significant effect on purchasing decisions, this result is proven by a significance value greater than 5\%. Brand awareness also has a significant effect on purchasing decisions, this result is evidenced by the significance value greater than 5\%. Perception of Price has a significant effect on purchasing decisions, this result is evidenced by the significance value greater than $5 \%$.
\end{abstract}

Keywords: brand image, brand awareness, price perception, buying decision, imported, cosmetics

\section{PENDAHULUAN}

Perkembangan globalisasi membuat minat perempuan di Indonesia terhadap kosmetik semakin meningkat karena masyarakat Indonesia sudah dimudahkan dalam mengakses berbagai macam informasi, dalam hal ini mengenai kosmetik. Bagi wanita,produk kosmetik selalu menjadi bagian dari kehidupan sehari-hari, demi mempertahankan dan mendapatkan kecantikan dari waktu ke waktu karena penampilan fisik bagi wanita merupakan hal yang sangat penting Dalam hal pembelian kosmetik tidak terlepas dari faktor-faktor yang mempengaruhi di dalamnya, dan presepsi konsumen merupakan salah satu 
faktor yang mempengaruhi keputusan pembelian konsumen. Seperti merek kosmetik, kualitas kosmetik,kandungan kosmetik, serta harga kosmetik itu sendiri (Ummu, 2016). Wanita di Indonesia memilih kosmetik berdasarkan gaya hidup dan pasti memilih yang terbaik, biasanya kosmetik yang digunakan berasal dari kosmetik high brand yang terkenal dan merupakan kosmetik yang diimpor dari berbagai negara seperti Korea, China, Prancis, Amerika,dan Eropa yang merupakan produsen kosmetik terbaik di pasar global (A. Akram, 2011).

Konsumen kosmetik menganggap kosmetik impor lebih mudah digunakan, misal dalam kemasan produk, pigmentasi warna dsb. Tingginya permintaan pasar produk premium dan bermerek, membuat pasar kecantikan di Indonesia banyak mengimpor produk kosmetik dari luar. Kepala Badan Pengawas Obat

Dan Makanan (BPOM) menjelaskan bahwa sedikitnya notifikasi produk kosmetik lokal dibandingan kosmetik impor dikarenakan kemampuan industri yang masih lemah. Menurut Ketua Umum Perusahaan Dan Asosiasi Kosmetika

(PPAK),Putri K. Warhani mengatakan dominasi produk kosmetik impor menguasai penjualan peritel atau departement store, sehingga mempersempit kesempatan produk kosmetik lokal untuk bersaing (Kementrian Perindustrian, 2016).Peningkatan penjualan kosmetik impor juga terjadi karena pemberlakuan perdagangan bebas antara negara-negara ASEAN. Pemberlakuan harmonisasi tarif impor di negara- negara ASEAN sebagai dampak perdagangan bebas, mengakibatkan prosedur impor menjadi lebih mudah apalagi dengan adanya penurunan tarif bea masuk. Impor produk kosmetik Indonesia terindikasikan masih melonjak setiap tahunnya, sementara itu jumlah impor produk kosmetik di periode Januari-juli 2019 sudah tercatat sebesar US\$208,06 juta . Nilai itu sudah melambung dari impor periode Januari-juli 2018 yang sebesar US\$

194,25 juta. Nilai impor kosmetik Indonesia mengalami fluktuasi trend pertumbuhan sebesar 111,84\% dari periode 2013-2018. (Kementrian Perindustrian, 2019).

Berdasarkan latar belakang permasalahan yang telah dibuat, tujuan dari penelitian ini adalah menganalisis pengaruh brand images, brand awareness, dan presepsi harga terhadap keputusan pembelian kosmetik impor. Hasil penelitian ini diharapkan berguna bagi peneliti selanjutnya dan pihak lainnya. Hipotesis dari penelitian ini menyatakan bahwa brand image, brand awereness, dan presepsi harga berpengaruh signifikan terhadap keputusan pembelian kosmetik impor. Nilai ini signifikan pada tingkat signifikansi lebih besar dari $5 \%$, berarti hipotesis diterima.

\section{METODE PENELITIAN}

Jenis penelitian yang digunakan merupakan jenis penelitian eksplanatori (explanatory research), yaitu penelitian untuk mengetahui dan menjelaskan pengaruh antar variabel yang ada, serta dilanjutkan 
dengan pengujian-pengujian hipotesis yang telah dirumuskan sebelumnya dalam rangka untuk menjelaskan hubungan kausal antar variabel. Penelitian ini termasuk pula dalam penelitian deskriptif, karena memberi penjelasan secara deskriptif mengenai variabel-variabel yang hendak diteliti.Penelitian ini menggunakan pendekatan kuantitatif melalui metode survei dan dilakukan dengan pendekatan eksplanatori dengan menggunakan skala Likert. Responden diminta untuk menyampaikan tingkat kesetujuannya tentang nilai-nilai dan pengaruh antar variabel yang diukur. Survei dilakukan melalui penyebaran kuesioner terhadap para responden, selanjutnya informasi yang diperoleh diolah dengan metode statistik menggunakan alat perangkat lunakStatistical Product and Service Solutions (SPSS) sampel yang digunakan merupakan sampel random sampling dengan subyek penelitian 144 responden. Penelitian yang dilakukan menjelaskan faktor- faktor apa saja yang mempengaruhi konsumen mengambil keputusan untuk membeli kosmetik impor. Penelitian ini menggunakan data primer yaitu data yang diperoleh melalui hasil penyebaran kuisioner kepada sejumlah responden yang menjadi subyek dari penelitian ini, yang diolah sedemikian rupa sehingga dapat menghasilkan temuan yang dimaksud dalam penelitian ini. Selain itu penelitian ini juga menggunakan data sekunder yaitu data pendukung yang biasanya dapat diperoleh dari literature-literatur bahan kepustakaan dan dokumen-dokumen yang berhubungan dengan masalah yang diteliti guna membangun sebuah konsep penelitian. Variabel penelitian ini terdiri atas variabel independen (brand image, brand awareness, dan presepsi harga) dan variabeldependen (keputusan pembelian kosmetik impor).

\section{HASIL DAN PEMBAHASAN}

Produk kosmetik impor merupakan produk kecantikan yang menjadi banyak pilihan bagi wanita Indonesia, dimana kebanyakan produk impor tersebut memiliki kualitas yang lebih daripada produk lokal. Produk kosmetik asing juga mempengaruhi keputusan pembelian konsumen seperti kandungan kosmetik, merek kosmetik serta harga kosmetik itu sendiri. Hal ini juga berlaku terhadap masyarakat di Samarinda dalam pengaruh pembelian kosmetik impor. Hasil uji validitas yang dilakukan terhadap sampel sebanyak 144 responden memperlihatkan, masing-masing nilai Pearson Correlation setiap indikator lebih besar dibanding nilai-nilai batas sebesar $r$ tabel alpha 5\% (nilai Pearson Correlation> Nilai Batas). Dengan demikian dapat dikemukakan bahwa semua indikator yang digunakan dalam penelitian ini dinyatakan valid atau sah untuk mengukur variabel penelitian sehingga dapat dilanjutkan untuk proses penelitian. 
Ekonomi dan Bisnis Vol. 24 No.2. November 2020 Fahira, Zafrullah, \& Setyaningrum

Tabel 1. Uji Validitas SPSS

\begin{tabular}{lrccc}
\hline Variabel & Indikator & r hitung & Nilai batas & Keterangan \\
\hline \multirow{3}{*}{ Brand Image } & BI1 & 0,782 & 0,3 & Valid \\
& BI2 & 0,705 & 0,3 & Valid \\
& BI3 & 0,674 & 0,3 & Valid \\
BI4 & 0,803 & 0,3 & Valid \\
\hline \multirow{3}{*}{ Brand Awareness } & BA1 & 0,711 & 0,3 & Valid \\
& BA2 & 0,803 & 0,3 & Valid \\
& BA3 & 0,682 & 0,3 & Valid \\
Persepsi Harga & BA4 & 0,651 & 0,3 & Valid \\
& PH1 & 0,949 & 0,3 & Valid \\
& PH2 & 0,791 & 0,3 & Valid \\
PH3 & 0,949 & 0,3 & Valid \\
\hline \multirow{3}{*}{ Keputusan Pembelian } & KP1 & 0,802 & 0,3 & Valid \\
& KP2 & 0,687 & 0,3 & Valid \\
& KP3 & 0,728 & 0,3 & Valid \\
& KP4 & 0,752 & 0,3 & Valid \\
\hline
\end{tabular}

Sumber: Data diolah dengan SPSS, 2019

Selanjutnya, uji reliabilitas digunakan untuk mengetahui indikator yang digunakan dapatdipercaya dan diandalkan sebagai alat ukur variabel. Hasil uji reliabilitas adalah sebagai berikut:

Tabel 2. Uji Reliabilitas SPSS

\begin{tabular}{crccc}
\hline No. & Variabel & $\begin{array}{c}\text { Croncbach' } \\
\text { alpha }\end{array}$ & $\begin{array}{c}\text { Nilai } \\
\text { Batas }\end{array}$ & $\begin{array}{c}\text { Keteranga } \\
\text { n }\end{array}$ \\
\hline 1. & Brand Image & 0,729 & 0,6 & Reliabel \\
2. & Brand Awareness & 0,675 & 0,6 & Reliabel \\
3. & Persepsi Harga & 0,876 & 0,6 & Reliabel \\
4. & Keputusan Pembelian & 0,702 & 0,6 & Reliabel \\
\hline
\end{tabular}

Sumber: Data diolah dengan SPSS, 2019

Berdasarkan tabel 2 di atas menunjukkan bahwa untuk sampel sebanyak 144 respondenuji reliabilitas dilakukan dengan cara one shot, yaitu apabila nilai Cronbach's alpha variabel > 0,60 maka indikator yang digunakan oleh variabel tersebut reliabel, sedangkan nilai Cronbach's alpha suatu variabel $<0,60$ maka indikator yang digunakan variabel tersebut tidak reliabel.

Berdasarkan hasil perhitungan diperoleh nilai Cronbach's alpha masing-masing butir pertanyaan telah memenuhi syarat realibilitas, yaitu nilai cronbach's alpha masing-masing butir pertanyaan tersebut telah melebihi syarat minimal tingkat reliabilitas atau cronbach's alpha $>0,60$.Hal 
ini menunjukkan bahwa dari butir pertanyaan yang diajukan semuanya reliabel atau menghasilkan nilai yang sama apabila diajukan berulang dua kali atau lebih.

\section{Pengujian dan Hasil Analisis Data}

Penelitian ini menggunakan random sampling yaitu, memungkinkan setiap elemen populasi mempunyai peluang yang sama untuk terpilih menjadi sampel yang sesuai dengan kriteria-kriteriayang telah ditentukan dan sudah memutuskan pembelian kosmetik impor. Subyek penelitian yang digunakan sebanyak 144 responden. Berikut hasil analisis regresi berganda menggunakan program SPSS 24.

TABEL 3. Hasil Analisis Regresi Berganda Coefficients $^{\text {a }}$

\begin{tabular}{llccccc}
\hline \multirow{2}{*}{ Model } & \multicolumn{2}{c}{ Unstandardized } & \multirow{2}{*}{$\begin{array}{c}\text { Standardized } \\
\text { Coefficients }\end{array}$} & T & Sig. \\
\cline { 2 - 4 } & & $\mathrm{B}$ & Std. Error & & & \\
\hline 1 & (Constant) & .862 & .235 & & 3.668 & .000 \\
& Brand Image & .167 & .065 & .174 & 2.574 & .011 \\
& Brand Awareness & .469 & .073 & .489 & 6.454 & .000 \\
& Persepsi Harga & .158 & .062 & .198 & 2.540 & .012 \\
\hline
\end{tabular}

Sumber: Data diolah oleh SPSS,2019

Berdasarkan tabel diatas dapat diperoleh persamaan linear berganda sebagai berikut:

$$
\mathrm{Y}=0.862+0.167 \mathrm{X}_{1}+0.469 \mathrm{X}_{2}+0.158 \mathrm{X}_{3}-235
$$

Keterangan :

0.862 : Variabel independen yaitu Brand Image, Brand Awareness dan Persepsi Harga mempunyai hubungan positif dengan Keputusan Pembelian. Nilai konstanta Keputusan Pembelian sebesar 0.862 menunjukkan bahwa semakin meningkatnya Keputusan Pembelian.

0.167X $\mathrm{X}_{1}$ : Besarnya koefisien variabel Brand Image yang berarti setiap peningkatan variabel Brand Image sebesar 1\%, maka Keputusan Pembelian meningkat

0.167 dengan asumsi variabel lainnya konstan.

$0.469 \mathrm{X}_{2}$ : Besarnya koefisien variabel Brand Awareness yang berarti setiap peningkatan variabel Brand Awareness sebesar 1\%, maka Keputusan Pembelian meningkat 0.469 dengan asumsi variabel lainnya konstan. 
0. $158 \mathrm{X}_{3}$ : Besarnya koefisien variabel Persepsi Harga yang berarti setiap peningkatan variabel Persepsi Harga sebesar 1\%, maka Keputusan Pembelian meningkat 0.158 dengan asumsi variabel lainnya konstan. Standar error sebesar 235 artinya seluruh variabel yang dihitung dalam uji SPSS memiliki tingkat variabel pengganggu sebesar 0.235. Hasil regresi berganda di atas menunjukkan bahwa variabel bebas yakni Brand Image, Brand Awareness dan Persepsi Harga, berpengaruh positif terhadap variabel terikat yakni Keputusan Pembelian. Di mana setiap kenaikan yang terjadi pada variabel bebas akan diikuti pula oleh kenaikan variabel terikat. Selain itu dari hasil tersebut dapat dilihat bahwa variabel bebas yang dominan adalah variabel Brand Awareness sebesar 0.469.

\section{KESIMPULAN}

Berdasarkan hasil penelitian dan pembahasan terkait brand memberikan pengaruh terhadap tingginya pembelian produk kosmetik impor, maka dapat ditarik beberapa kesimpulan sebagai berikut:

1. Dalam penelitan ini brand image terbukti memiliki pengaruh terhadap keputusan pembelian kosmetik impor secara positif dan signifikan. Hal ini ditujukkan dari nilai thitung sebesar 2,574 dengan nilai signifikansi 0,011 dimana signifikansi lebih kecil dari $0,05(0,011<0,05)$, dan koefisien regresi mempunyai nilai positif sebesar 0,167 . yang artinya brand image memiliki pengaruh sebesar $16,7 \%$ terhadap keputusan pembelian kosmetik impor. Besarnya pengaruh brand image dalam sikap konsumen bisa terjadi karena dalam memutuskan membeli kosmetik Impor. Hasil penelitian ini mendukung penelitian yang dilakukan (Prasetya, 2018) yang menunjukkan brand image mempunyai pengaruh positif dan signifikan terhadap keputusaan pembelian.

2. Dalam penelitan ini brand awareness terbukti memiliki pengaruh terhadap keputusan pembelian kosmetik impor secara positif dan signifikan. Hal ini ditujukkan dari nilai t hitung sebesar 6,454 dengan nilai signifikansi 0,000 dimana signifikansi lebih kecil dari 0,05 $(0,000<0,05)$, dan koefisien regresi mempunyai nilai positif sebesar 0,469. yang artinya brand awareness memiliki pengaruh sebesar 46,9\% terhadap keputusan pembelian kosmetik impor. Dapat disimpulkan bahwa responden memperhatikan brand awareness dalam proses pembentukan keputusan pembelian kosmetik impor dalam benak mereka. Hasil peneilitian ini mendukung penelitian yang dilakukan (Wibowo, 2017), yang menunjukkan brand awareness mempunyai pengaruh positif dan signifikan terhadap keputusaan 
Ekonomi dan Bisnis Vol. 24 No.2. November 2020 Fahira, Zafrullah, \& Setyaningrum

pembelian

3. Dalam penelitan ini presepsi harga terbukti memiliki pengaruh terhadap keputusan pembelian kosmetik impor secara positif dan signifikan. Hal ini ditujukkan dari nilai t hitung sebesar 2,540 dengan nilai signifikansi 0,012 dimana signifikansi lebih kecil dari 0,05 $(0,012<0,05)$, dan koefisien regresi mempunyai nilai positif sebesar 0,158 . yang artinya presepsi harga memiliki pengaruh sebesar $15,8 \%$ terhadap keputusan pembelian kosmetik impor. Dapat disimpulkan bahwa responden memperhatikan presepsi harga dalam proses keputusan pembelian kosmetik impor. Hasil peneilitian ini mendukung penelitian yang dilakukan (Prayoga, 2015) yang menunjukkan Persepsi Harga mempunyai pengaruh positifdan signifikan terhadap keputusaan pembelian.

\section{DAFTAR PUSTAKA}

A. Akram, D. M. (2011). Perceived brand globalness in emerging markets and the modeling role of consumer ethnocentrism. Int. J. Emerg. Mark, 291-303.

Kementrian Perindustrian. (2016). Produk Impor Kuasai Pasar Kosmetik. Diambil kembali dari Kemenperin Perindustrian: https://kemenperin.go.id/artikel/11943/Produk-Impor- Kuasai-PasarKosmetik.

Kementrian Perindustrian. (2019). Impor Kosmetik RI,Perkembangan Kosmetik Impor 2013-2018.Pemerintah, Perindustrian. jakarta: Kementrian Perindustrian.

Prasetya, E. Y. (2018). Pengaruh Brand Image terhadap Keputusan Pembelian.

Prayoga, C. B. (2015). Pengaruh Persepsi Harga dan Promosi terhadap Keputusan Pembelian Konsumen Produk Enervon-C. 1.

Ummu, H. (2016). Pengaruh kualitas produk dan switching barrier terhadap keputusan Pembelian Produk Kosmetik Wardah di Kota Bangkalan Madura.

Wibowo, N. E. (2017). Pengaruh Brand Awarness terhadap Keputusan Pembelian (Studi Kasus Yellow Truck Cabang Sunda Bandung). 